\title{
Nutrient supply in the Southern East China Sea after Typhoon Morakot
}

\author{
by Chin-Chang Hung ${ }^{1,2,3}$, Chih-Ching Chung ${ }^{3}$, Gwo-Ching Gong ${ }^{3,4,9}$, Sen Jan ${ }^{5}$, \\ Yaling Tsai ${ }^{5}$, Kuo-Shu Chen ${ }^{1}$, Wen Chen Chou ${ }^{3}$, Ming-An Lee ${ }^{6}$, Yi Chang ${ }^{7}$, \\ Meng-Hsien Chen ${ }^{8}$, Wen-Rong Yang ${ }^{9}$, Chiung-Jung Tseng' and \\ Glen Gawarkiewicz ${ }^{10}$
}

\begin{abstract}
Recent studies show that typhoons have profound effects on phytoplankton assemblages along their tracks, but it is difficult to quantitatively estimate nutrient supply after a typhoon's passage due to a lack of nutrient information before and after the arrival of a typhoon. During the passage of Typhoon Morakot (July 22 to Aug. 26, 2009), we conducted pre- and post-typhoon field cruises to study nutrient supply in the Southern East China Sea (SECS). The results showed nitrate and phosphate supplies to the water column in the SECS after the typhoon's passage were $5.6 \times 10^{11} \mathrm{~g}-\mathrm{N} / \mathrm{day}$ and $7.8 \times 10^{10} \mathrm{~g}$-P/day which were significantly higher than those before the typhoon occurred (nitrate supply $=1 \times 10^{9} \mathrm{~g}-\mathrm{N} /$ day, phosphate supply $=1.6 \times 10^{8} \mathrm{~g}$-P/day). We conclude from this data, and after consulting the available physical data, that the highest nitrate concentration was caused by strong upwelling and/or vertical mixing, and input of nutrient-replete terrestrial waters. The nitrate and phosphate input related to the passage of Typhoon Morakot can account for approximately $86 \%$ and $87 \%$ of summer nitrate and phosphate supplies to the southern East China Sea.
\end{abstract}

1. Institute of Marine Geology and Chemistry, and Asia-Pacific Ocean Research Center, National Sun Yat-sen University, Kaohsiung, 80424, Taiwan

2. Corresponding author e-mail: cchung@mail.nsysu.edu.tw

3. Institute of Marine Environmental Chemistry and Ecology, National Taiwan Ocean University, Keelung, 20224, Taiwan

4. Center of Excellence for Marine Bioenvironment and Biotechnology, National Taiwan Ocean University

5. Institute of Oceanography, National Taiwan University, Taipei, Taiwan

6. Department of Environmental Biology and Fisheries Science, National Taiwan Ocean University

7. Institute of Ocean Technology and Marine Affairs, National Cheng Kung University, Tainan, Taiwan

8. Department of Marine Biotechnology and Resources, National Sun Yat-sen University, Kaohsiung, Taiwan

9. Taiwan Ocean Research Institute, National Applied Research Laboratories, Kaohsiung, Taiwan

10. Woods Hole Oceanographic Institution, Woods Hole, MA, USA

(C) 2013 Chin-Chang Hung, Chih-Ching Chung, Gwo-Ching Gong, Sen Jan, Yaling Tsai, Kuo-Shu Chen, Wen Chen Chou, Ming-An Lee, Yi Chang, Meng-Hsien Chen, Wen-Rong Yang,

Chiung-Jung Tseng and Glen Gawarkiewicz. 


\section{Introduction}

The East China Sea (ECS) is one of the largest marginal seas in the western Pacific Ocean. The southern East China Sea (SECS), one of the largest fishing regions in the western Pacific Ocean, is located near the northern tip of Taiwan. Mackerel and swordtip squid are two of the most important fishery resources in the SECS, with a production season from approximately spring to early winter (Sassa et al., 2008; Wang et al., 2008). Elevated phytoplankton biomass on the SECS shelf break has been documented (Gong et al., 1995, 2000; Chen et al, 2001) and likely provides an abundant source of food for both adult and larval mackerels (Sassa et al., 2008). Researchers found recurring upwelling events off northeast Taiwan in the SECS (Chern et al., 1990; Liu et al., 1992; Jan et al., 2011; Hung and Gong, 2011), and with it, transport of nutrients, mainly from subsurface Kuroshio waters, onto the shelf. However, some reports suggest that phytoplankton growth in the SECS is limited in the summer due to nutrient deficiency (Gong et al., 1995; Chen et al., 2001; Liu et al., 2010).

Extreme atmospheric events, such as dust storms or typhoons, were documented to enhance nutrient supply, induce storm surges, influence marine biological activity and geochemical cycling of many elements (including organic materials) and pollutant discharge (Chen et al., 2003, 2009; Walker et al., 2005, 2006; Chung et al., 2011, 2012; Zhao et al., 2008; Siswanto et al., 2007, 2008, 2009; Hung et al., 2005, 2007, 2009, 2010; Li et al., 2010; Hung and Gong, 2011; Chou et al., 2011; Liu et al., 2013). According to historical typhoon records, several typhoons affect the East China Sea each year (www. cwb.gov.tw). Usually, nutrients provided by oceanic (vertical mixing or upwelling) and terrestrial (precipitation and/or river discharges) inputs are the two most important sources for phytoplankton growth (Zheng and Tang, 2007; Zhao et al., 2008; Chen et al., 2009; Hung et al., 2012; Chung et al., 2012), but it is difficult to demonstrate specific biogeochemical processes that are influenced by typhoons because of a lack of sea-going investigations. Although Hung et al. (2010) conducted a comprehensive survey in the SECS to examine the role of typhoons on ocean properties and particulate organic carbon (POC) flux, the authors did not provide pre-typhoon hydrographic settings and POC flux. More recently, Chung et al. (2012) reported detailed nutrients (including nitrate, nitrite, phosphate and silicate) dynamics and population dynamics of microphytoplankton in the SECS before and after typhoon Morakot. Chung et al. (2012) concluded that typhoon Morakot caused numerous nutrient supply from vertical mixing, upwelling and nutrient-rich floodwaters with low N:P ratios (3 5), driving a diatom bloom in the SECS after Typhoon Morakot. The diatom bloom was inhibited approximately in a short period of time, they suggested that grazing pressure and/or the possibility of dilution with ambient water masses are two main factors (Chung et al., 2012). Chung et al. (2012) provided valuable hydrographic and nutrient data before and after Typhoon Morakot, but they did not quantitatively estimate nutrient supply from both oceanic and terrestrial sources.

Typhoon Morakot, affecting the East China Sea from Aug. 7-9, 2009, was the most lethal typhoon hitting Taiwan in recorded history (Yen et al., 2011). The typhoon dumped 


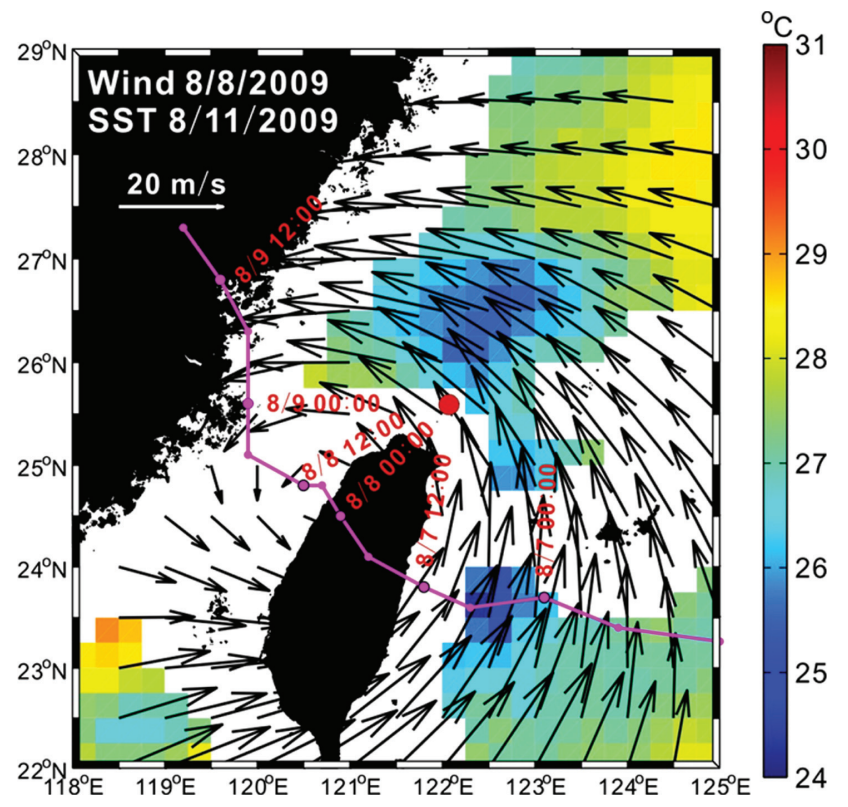

Figure 1. Study area (hydrographic location: a red spot), track (pink line), AMSR-E fusion sea surface temperature (SST, Aug. 11) and Quik Scan sea surface winds (Aug. 8, from www.remss.com) during Typhoon Morakot in 2009 in the Southern East China Sea.

extremely high amounts of rainfall, peaking at 2,780 $\mathrm{mm}$ in Taiwan, and resulted in severe flooding in southern Taiwan (Huang et al., 2011). In this paper, we present detailed hydrographic and nutrient data during the pre- and post-typhoon periods to estimate contributions of oceanic and terrestrial nutrients in a marginal sea after a typhoon event. Herein we will use nitrogen supply as an example because phosphate and silicate are not limiting factors for phytoplankton blooms in the Southern East China Sea (Chung et al., 2012).

\section{Materials and methods}

Seven sea-going biogeochemical expeditions were conducted in the SECS near the northeast of Taiwan $\left(25.45^{\circ} \mathrm{N}, 122.00^{\circ} \mathrm{E}\right.$, the sampling location is the red dot in Figure 1, bottom depth $\sim 130$ to $150 \mathrm{~m}$ ) during the periods before and after Morakot. The hydrographic surveys at sampling location (the red dot in Fig. 1) and adjacent areas have been observed for over 10 years under good weather conditions in summer and seldom conducted after a typhoon passed. In addition, based on previous investigations either field cruises or satellite image observations, the upwelling phenomenon at the sampling region after a typhoon is remarkable (Chang et al., 2008; Hung et al., 2010). Five cruises aboard the R/V Ocean Researcher II (OR-II) were made in each of the following periods: July 22, Aug. 5, Aug. 11-2, Aug. 18-19 and Aug. 25-26, 2009. The other two cruises were conducted on Aug. 14 
and 16 aboard the fishing boat Yang-Ming. It is noted that we only had surface hydrographic data on Aug. 5 due to winch failure. Besides, two hydrographic (salinity and temperature only) cruises were conducted in a large region of the SECS (detailed cruise information shown in Jan et al., 2013) during Aug. 13-17, and Aug. 21-27, 2009 after Morakot. Aboard the OR-II, the water temperature and salinity were measured with a conductivity/temperature/depth recorder (CTD) (SBE911 plus, SeaBird). The surface salinity and temperature data along the ship track were continually recorded by a surface thermosalinograph (SBE21, SeaBird). Salinity, temperature, density and beam attenuation (e.g. transmissometer profiles) were recorded using a SeaBird model SBE9/11 plus conductivity/temperature/depth (CTD) recorder and a transmissometer (Wet Labs). The mean downwelling attenuation coefficient $\left(\mathrm{K}_{\mathrm{PAR}}\right)$ was obtained from a PAR scalar quantum irradiance sensor (Chelsea Technologies Group Ltd, UK). The depth of the euphotic depth (EZ) was defined as the depth of $1 \%$ surface light penetration $\left(=4.605 / \mathrm{K}_{\mathrm{PAR}}\right)$. The bottom of mixed layer was defined as the depth at which the temperature was $0.5^{\circ} \mathrm{C}$ lower than that at the surface.

Samples were collected using 20-L Niskin bottles mounted on the CTD rosette. Aboard the Yang-Ming, water samples from specific depths in the water column were collected using a 10-L Niskin bottle connected with a nylon rope. The water samples were further processed for determination of $\mathrm{Chl} a$ and nutrient concentrations. The concentrations of nitrate $\left(\mathrm{NO}_{3}\right)$, phosphate $\left(\mathrm{PO}_{4}\right)$ and chlorophyll $a(\mathrm{Chl} . a)$ at depths of $0,10,25,50$, 75 and $100 \mathrm{~m}$ were determined according to Gong et al. (2000). However, we did not measure concentrations of ammonium and dissolved organic nitrogen in this study. Briefly, the Chl. $a$ samples were collected by filtering $500 \mathrm{ml}$ of seawater through a GF/F filter and stored at $-20^{\circ} \mathrm{C}$ until analysis. $\mathrm{Chl} a$ on the $\mathrm{GF} / \mathrm{F}$ filter was extracted by acetone and its concentration was determined using a Turner Designs 10-AU-005 fluorometer by the non-acidification method (Gong et al. 2000). The sea surface temperatures (SST) in the SECS were estimated (resolution $1.1 \mathrm{~km}$ ) before and after the passage of Typhoon Morakot using AVHRR (Advanced Very High Resolution Radiometer) infrared sensors (Chang et al., 2008).

\section{Results}

\section{a. Hydrographic settings before typhoon passage}

Typhoon Morakot, a category-2 typhoon ( $\sim$ sustained wind $\left.\sim 40 \mathrm{~m} \mathrm{~s}^{-1}\right)$, started to affect the SECS on Aug. 6, 2009 and made landfall on the eastern side of Taiwan on Aug. 8, 2009 (Fig. 1). The strongest wind that swept over SECS was from Aug. 7-9 (Fig. 1). The AVHRR-derived SSTs in the study region before and after the typhoon are shown in Figure 2, with warm water occurring on Aug. 5 and cold water occurring after Aug. 11. The area of the cold water from Morakot also contained water from record-breaking rainfall in the southern Taiwan. Within two days (Aug. 8-9), freshwater in excess of $3 \times 10^{10} \mathrm{~m}^{3}$ 

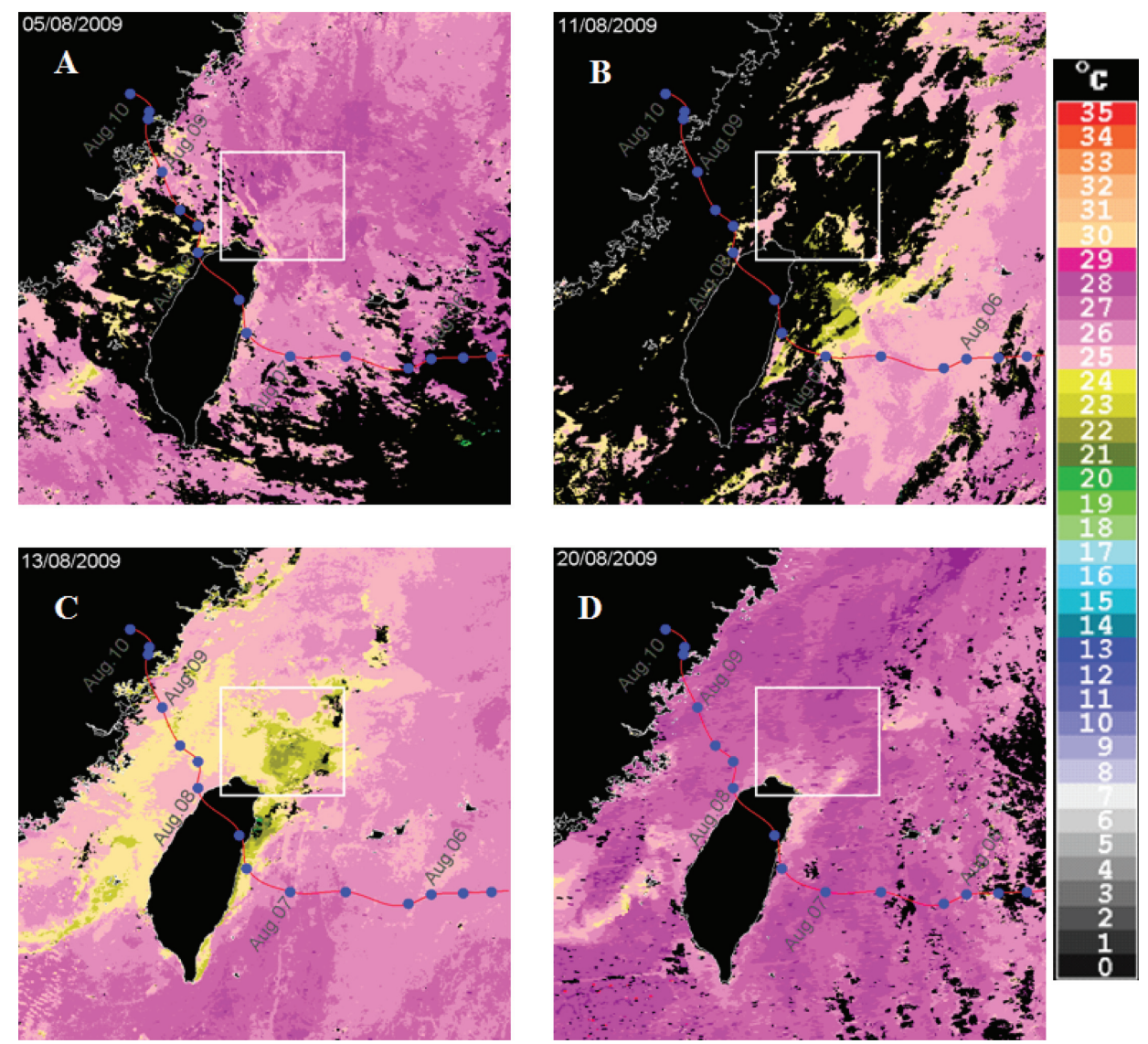

Figure 2. AVHRR satellite images before (A) and after (B, C, D) the typhoon. The red lines represent the typhoon moving track of Morakot. (A) warm water appeared in the southern East China Sea on Aug. 5. (B) Typhoon Morakot just passed the SECS with heavy cloud cover (black color) on Aug. 11. (C) cold water patch appeared in the SECS on Aug. 13 and (D) warm water appeared in the SECS on Aug. 20.

from the flooded areas was injected into the southern Taiwan Strait (Water Resource Bureau, Taiwan, www.wra.gov.tw, also see data in Jan et al., 2013).

Under non-typhoon conditions, the surface water temperature was about $\sim 28^{\circ} \mathrm{C}$ (e.g. July 22) (or $29.6^{\circ} \mathrm{C}$ on Aug. 5) in the surface layer and decreased to $16^{\circ} \mathrm{C}$ at $100 \mathrm{~m}$ (Fig. 3A). The vertical variation in salinity ranged from 33.6 to 34.5 (Fig. 3B). The concentrations of nitrate and phosphate $\left(\mathrm{PO}_{4}\right)$ were initially at low levels in the surface layer and increased to $2.0 \mu \mathrm{M}$ and $0.23 \mu \mathrm{M}$ at $25 \mathrm{~m}$, respectively (Fig. 3C). The concentration of chlorophylla (Chl.a) was $0.44 \mathrm{mg} / \mathrm{m}^{3}$ in the surface layer and gradually increased to $0.98 \mathrm{mg} / \mathrm{m}^{3}$ at $25 \mathrm{~m}$. The vertical hydrographic settings on July 22 were similar to previous surveys 

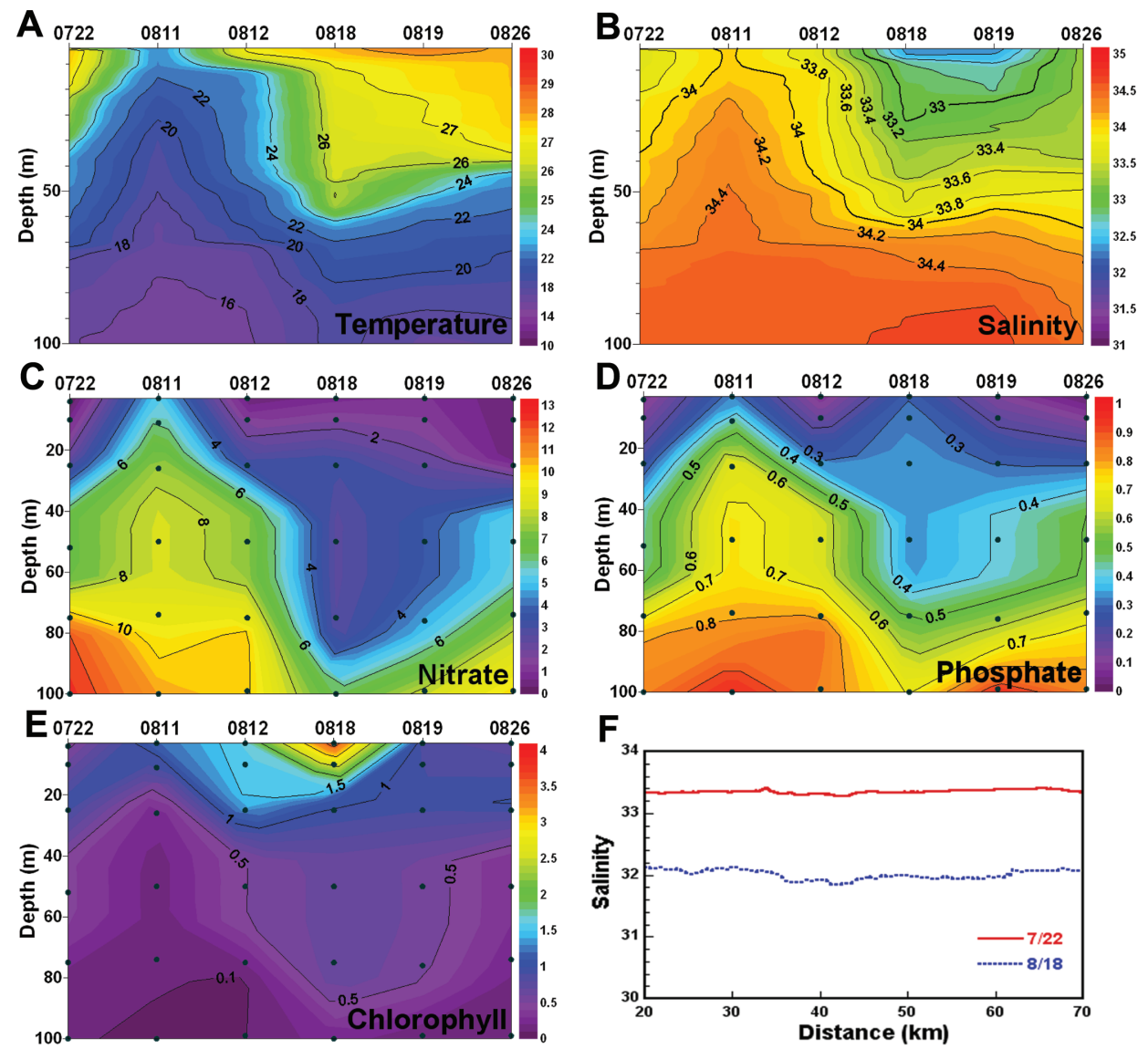

Figure 3. Contoured profiles of (A) temperature $\left({ }^{\circ} \mathrm{C}\right)$, (B) salinity, (C) nitrate, (D) phosphate, (E) Chlorophyll $a$ in the study area before and after Typhoon Morakot. (F) Surface salinity along the ship track from the north coast of Taiwan $20 \mathrm{~km}$ away from Keelung Harbor $\left(25.17^{\circ} \mathrm{N}, 121.80^{\circ}\right.$ E) to the study site. The salinities pre- and post-Typhoon Morakot are denoted by the red and blue lines, respectively.

(Gong et al. 2000, Liu et al. 2010) and represented the typical summer conditions without episodic disturbances (Gong et al., 2003; Hung and Gong, 2011). For example, Chen (2000) reported that the surface Chl. $a$ values ranged from 0.71 to $1.51 \mathrm{mg} \mathrm{m}^{-3}$ in a similar area of the SECS in April and June. Gong et al. (2003) reported results from four cruises covering four seasons and found higher surface Chl. $a$ concentrations $\left(\sim 1 \mathrm{mg} \mathrm{m}^{-3}\right)$ occurring in autumn and winter, and lower surface Chl. $a$ values $\left(\sim 0.3-0.4 \mathrm{mg} \mathrm{m}^{-3}\right)$ in summer. These results demonstrate that our field observations for Chl. $a$ distribution patterns during nontyphoon conditions are in agreement with previous studies, particularly the low Chl. $a$ concentrations during summer under good weather conditions. 


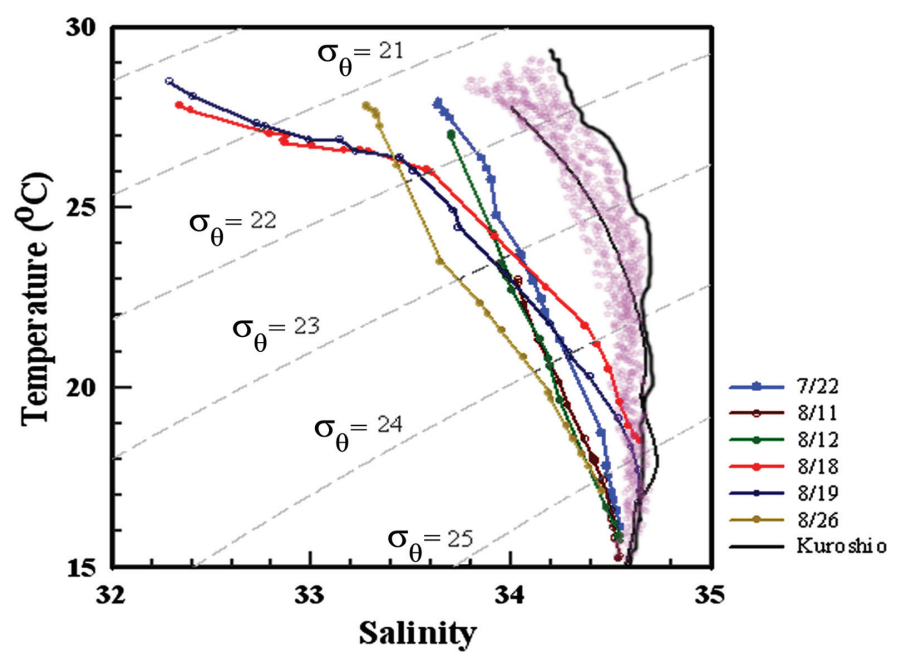

Figure 4. Diagrams of T $-\mathrm{S}-\sigma_{\theta}$ in the southern East China Sea. A black curve represents the characteristics of the Kuroshio Current; light pink dots represent the nature of the upwelled water from the shallow water (i.e. weak upwelling) of the Kuroshio Current under non-typhoon condition; a blue curve represent the nature of the upwelled water before a typhoon event. Brown and green curves represent the nature of the upwelled water from the deeper water of the Kuroshio upwelling after a typhoon event on Aug. 11 and 12, respectively. Red, dark blue and yellow curves represent the upwelled water from the shallow water of the Kuroshio Current on Aug. 18, 19 and 26, respectively. One can clearly see the huge freshwater plume mixed with ambient seawater on Aug. 18 and 19.

\section{b. Hydrographic settings after Typhoon Morakot's passage}

Both satellite-derived SSTs (Fig. 2) and cruise SST data (Fig. 3A) show marked cooling in the SECS after the passage of Typhoon Morakot. For example, the average sea-going SST at the study area (e.g. $25.45^{\circ} \mathrm{N}, 122.00^{\circ} \mathrm{E}$ ) decreased from $29.6^{\circ} \mathrm{C}$ on Aug. 5 (before the typhoon) to $23^{\circ} \mathrm{C}$ on Aug. 11 (after the typhoon) and then gradually increased to $28^{\circ} \mathrm{C}$ on Aug. 26 (about three weeks after the passage of the typhoon). The area of the cold water patch (defined as SST $<27^{\circ} \mathrm{C}$ ) increased gradually from $1,200 \mathrm{~km}^{2}$ on Aug. 5 to $5,800 \mathrm{~km}^{2}$ on Aug. 11, 32,000 km ${ }^{2}$ on Aug. 13 and then decreased to 1,300 km ${ }^{2}$ on Aug. 17 (Fig. 2). As a whole, the average cold water area in the SECS pre-typhoon conditions increased to approximately $30,000 \mathrm{~km}^{2}$ from $1,900 \mathrm{~km}^{2}$ during Aug. 3-5.

A diagram of temperature $(\mathrm{T})$, salinity $(\mathrm{S})$ and potential density $\left(\sigma_{\theta}\right.$, where $\theta$ is the potential temperature) at the study area is shown in Figure 4. The black curve shows the characteristics of the Kuroshio Current in the SECS. The light pink dots represent the nature of the upwelled water from the shallow water of the Kuroshio Current under non-typhoon periods. On July 22 (a blue line at Fig. 4), the water temperature was $\sim 28^{\circ} \mathrm{C}$ in the surface layer and $\sim 17^{\circ} \mathrm{C}$ at $100 \mathrm{~m}$, and the salinity ranged from 33.6 to 34.5 . After the passage of Morakot, the hydrographic settings changed significantly and revealed the occurrences 
of upwelling and the consecutive influx of lower salinity water (brow and green curves in Fig. 4) in the SECS. On the third day (Aug. 11) after Morakot, deep nutrient-replete water was brought to the surface from the Kuroshio subsurface upwelling. The SST dramatically declined to $22.9^{\circ} \mathrm{C}$, and the salinity in the water column remained high at 34 to 34.5 (brown curve in Fig. 4, Fig. 3B). On Aug. 12, the upwelling phenomenon terminated and the water column was stratified with a clear thermocline (Fig. 3A). The water masses with lower salinity (<33) were found over the surface layer on Aug. 18 and 19 (Fig. 3B and Fig. 4). The surface salinity along the ship track $20 \mathrm{~km}$ away from the Keelung Harbor to the study area also showed lower values below 33 as compared to pre-typhoon conditions (Fig. 3F). The detailed evidence of freshwater discharge and transport to the SECS is discussed by Jan et al. (2013). Subsequently, this lower-salinity water mass gradually mixed with ambient oceanic water. The hydrographic natures on 26 August had returned to the conditions present before Morakot passed. This cooling phenomenon caused by upwelled Kuroshio subsurface water in the SECS after the passage of a typhoon has frequently been observed before (Chang et al., 2008; Tsai et al., 2008; Zhao et al., 2008; Siswanto et al., 2007, 2009; Hung et al., 2010; Hung and Gong, 2011). The mechanisms of typhoon-induced SST cooling have previously been studied by Tsai et al. (2008) and Morimoto et al. (2009). These authors reported the typhoon triggers the intrusion of the subsurface Kuroshio water onto the shelf through complicated interactions of wind, current, and topography, causing the decreases in SST off the northeastern coast of Taiwan. Detailed processes involved in the Morakotinduced Kuroshio water intrusion and the associated decrease in SST can be found in Tsai et al. (2013).

After the passage of Morakot, the surface concentrations of nitrate and phosphate were at high values of 5.4 and $0.3 \mu \mathrm{M}$, respectively (Fig. 3A, B). The nitrate and phosphate concentrations in the mixed layer quickly declined to undetectable levels within one day (Fig. 3C, D). However, the vertical contours of nitrate and phosphate revealed that the terrestrial nutrient influx initially emerged in the surface layer on Aug. 14 and gradually occupied the upper $50 \mathrm{~m}$ of the water column on Aug. 18 (Fig. 3C, D). Numerous dissolved nutrients were carried with the lower-salinity water intrusion with an elevated nitrate concentration $(1.1 \mu \mathrm{M})$ on Aug. 19 and then gradually decreased to lower levels $(\sim 0.5 \mu \mathrm{M})$ on Aug. 26 (Fig. 3C). Similar to nitrate, the surface phosphate concentrations remained at high levels $(>0.2 \mu \mathrm{M})$ during the period between Aug. 16 and 18, and then returned to background levels ( $\sim 0.02 \mu \mathrm{M}$, e.g. before Morakot) on Aug. 26 (Fig. 3B). The distribution of surface nutrient concentrations in the study area coincided with anomalies of temperature and salinity patterns, with a higher peak on Aug. 11 and medium peak on Aug. 18.

The molar ratios $(\mathrm{N} / \mathrm{P})$ of integrated $(0-75 \mathrm{~m})$ nitrate (including very low nitrite concentration (less $\sim 5 \%$ of nitrate) to phosphate ranged from 7.3 to 13.5 with the highest value on July 22 and the lowest value on Aug. 18. These results suggest that phosphate is a not a limiting factor for phytoplankton growth in the SECS because the N/P ratios are lower than the Redfield ratio ( $\mathrm{N}: \mathrm{P}=16)$. We found that $\mathrm{Si} / \mathrm{N}$ ratios ranged from 1.6 to 2.9 in the 
SECS before and after Typhoon Morakot, suggesting that silicate is not a limiting factor for phytoplankton. The detailed data of nitrite, nitrate and silicate can be found in Chung et al. (2012).

\section{Discussion}

\section{a. Nitrate supply from oceanic source during non-typhoon conditions}

The surface maximum nitrate concentrations in the study area two-three days after the passage of Typhoon Morakot were 5.1 $\mu \mathrm{M}$ (Fig. 4). In comparison, surface nitrate concentrations during non-typhoon conditions are very low or almost below detection limit $(<0.1$ $\mu \mathrm{M})$. Based on this fact, Typhoon Morakot indeed brought cold-nutrient-rich water up to the surface layer from subsurface and/or deep water because of strong winds and a slow transit speed (Babin et al., 2004; Zheng and Tang, 2007). Typhoons clearly provide a significant source of nitrate, but how important is nitrate supply induced by typhoons responsible for phytoplankton growth in the SECS in summer? First, we need to know how much the nitrate supply in the SECS is during non-typhoon conditions. According to monthly cruises (Gong et al., 1992; Liu et al., 1992), the estimated transport of upwelled water in the SECS in summer (e.g. July to Sept.) as about $0.2 \mathrm{~Sv}\left(1 \mathrm{~Sv}=10^{6} \mathrm{~m}^{3} \mathrm{~s}^{-1}\right)$ and the average upwelling area (here defined as SST $<27^{\circ} \mathrm{C}$ ) as approximately $2900 \mathrm{~km}^{2}$ (Liu et al., 1992) under good weather conditions (suitable for cruise investigations, roughly defined as wind speed less than $15 \mathrm{~m} \mathrm{~s}^{-1}$ or wave height less than $2 \mathrm{~m}$ ). This is equivalent to an upwelling velocity of $6 \mathrm{~m} /$ day. Similarly, Liu et al. (1992) also estimated that the average upwelling velocity in the SECS as approximately $5.4 \mathrm{~m} /$ day.

The average nitrate concentration in the water column $(0-75 \mathrm{~m})$ in the SECS in summer under non-typhoon conditions is about $2.67 \mu \mathrm{M}$ based on field observations (data extracted from Table 1 in Hung and Gong, 2011). Dissolved organic nitrogen (DON) data are currently not available from the upwelling water of the SECS. Alternatively, we found that DON approximately accounts for 10-20\% (on average 15\%) of DIN in both upwelling water (Alvarez-Salgado et al., 1999) and in the North East Pacific (Wong et al., 2002). If we used $15 \%$ of DON of total nitrate (referred from the data published by Alvarez-Salgado et al., 1999, and the data during all seasons published by Hung and Huang, 2005), the contribution of DON to nitrogen pool would be $0.4 \mu \mathrm{M}-\mathrm{N}$. The level of nitrogen associated with POC concentration in the water column must also be added to this nitrate budget. The average POC concentration in the water column $(0 \sim 75 \mathrm{~m})$ in the SECS in summer under non-typhoon conditions is $0.04 \mathrm{gC} / \mathrm{m}^{3}(=(3 \mathrm{~g} / \mathrm{m} 2) /(75 \mathrm{~m})$, data from Table 1 in Hung and Gong, 2011). Assuming Redfield stoichiometry (Redfield et al., 1963, C:N=6.6:1) because phytoplankton is the primary producer in the SECS (Chen and Chen, 2003), the POC concentrations would be associated with $0.51 \mu \mathrm{M}-\mathrm{N}\left(\left(=0.04 \mathrm{gC} / \mathrm{m}^{3}\right) \times 1000 / 12 / 6.6\right)$, as nitrate). Thus the net average nitrate concentration in the upper $75 \mathrm{~m}$ of the water column is $3.6 \mu \mathrm{M}\left(=2.67+0.4+0.51+0.03 \mu-\mathrm{mol} / \mathrm{L}\right.$ or $\left.\mathrm{m}-\mathrm{mol} / \mathrm{m}^{3}\right)$ in the summer. The estimated summer daily nitrate transport to the top $75 \mathrm{~m}$ will then be $8.7 \times 10^{8} \mathrm{~g} \mathrm{~N} /$ day $(=0.2$ $\left.\mathrm{Sv}\left(10^{6} \mathrm{~m}^{3} / \mathrm{s}\right) \times 3.6 \mathrm{mmol} / \mathrm{m}^{3}\right)$ under non-typhoon conditions if removal of the sinking 
nitrogen flux $\left(0.03 \mu \mathrm{M}-\mathrm{N}\right.$ ) is considered (POC flux $=160 \mathrm{mg}-\mathrm{C} / \mathrm{m}^{2} / \mathrm{d} /=160 / 12 / 6.6 / 75$ $\mathrm{m}=0.03 \mu \mathrm{M}-\mathrm{N}$, see detailed data in Hung and Gong, 2011).

More specifically, the average nitrate concentration in the water column $(0-75 \mathrm{~m})$ in the SECS in this study on July 22 (e.g. pre-typhoon period) was $2.89 \mu \mathrm{M}$ before Typhoon Morakot. Due to POC and DON data lacking before Morakot, we use the same POC values $(\sim 0.6 \mu \mathrm{M}-\mathrm{N})$ and DON computation $(\sim 15 \%$ of nitrate $=0.43 \mu \mathrm{M}-\mathrm{N})$ as the nitrate source under non-typhoon conditions. As a result, the average nitrate concentration in the upper $75 \mathrm{~m}$ of the water column is $3.95(=2.89+0.43+0.6+0.03) \mu \mathrm{M}$. The estimated daily water transport in the upwelling region $\left(1,900 \mathrm{~km}^{2}\right)$ was $0.11 \mathrm{~Sv}$ based on the average upwelling speed $(5.4 \mathrm{~m} /$ day $)$ in the SECS. The estimated daily nitrate transport to the top $75 \mathrm{~m}$ will be $5.7 \times 10^{8}(=3.95 \times 5.4 \times 1900 \times 14) \mathrm{gN} /$ day before Typhoon Morakot. The model estimated nitrate transport in the SECS is approximately $2 \times 10^{9} \mathrm{~g}-\mathrm{N} /$ day based on sea-going monthly investigations (Liu et al., 1992). If we consider the uncertainty of both methods, the estimated nitrate transport value $\left(\sim 1 \times 10^{9} \mathrm{~g}\right.$-N/day $)$ in this study is slightly lower than previously reported data by Liu et al. (1992) if monthly variations of nitrate transport are considered. Of course, nitrate transport in the summer in the SECS is much lower than in the cold seasons (fall to spring) (Gong et al., 1995; Hung and Gong, 2011), therefore, our estimated daily nitrate transport in the summer under non-typhoon conditions seems reasonable. In addition, we also can use a simple approach to estimate phosphate supply on the SECS before Typhoon Morakot. The average $(0-75 \mathrm{~m})$ ratio of N/P was 13.5 on July 22 , the estimated phosphate supply will be $1.6 \times 10^{8} \mathrm{~g}-\mathrm{P} / \mathrm{day}$.

\section{b. Nitrate supply from oceanic and terrestrial sources after typhoon conditions}

Data on the upwelling velocity caused by the typhoon, detailed upwelling area and nitrate concentrations in whole upwelled water are more difficult to obtain due to the severe weather conditions, but we attempted to estimate nitrate supply after Typhoon Morakot by making some reasonable assumptions. As previously described, the cold water patches due to upwelling after typhoons increased to approximately $32,587 \mathrm{~km}^{2}$ on Aug. 11 from 1,800 $\mathrm{km}^{2}$ on Aug. 3-5. As the average nitrate concentration in the water column $(0-75 \mathrm{~m})$ in the SECS two days (Aug. 11) after Typhoon Morakot was 7.54 $\mu \mathrm{M}$. Therefore, we use $7.5 \mu \mathrm{M}$ to represent the average nitrate concentration in the SECS after typhoons and do not consider the POC-nitrogen contribution because particles in fresh upwelling water is not as important as in aged upwelling water because both concentrations of particulate organic carbon $(\sim 1$ $\mu \mathrm{M}$, Liu et al., 1995) and chlorophyll (<0.1 $\mu \mathrm{g} / \mathrm{L}$, Hung et al., 2000) in fresh upwelling water is low. Although previous studies have shown that ammonium concentration can account for $20 \%$ of DIN in the coastal water (with the third World River, Changjiang) of the East China Sea (Li et al., 2009), our study area is far away from the Changjiang. Additionally, Hung et al. (2005) reported ammonium concentration only account for $<10 \%$ of DIN in the coastal water of Taiwan during all seasons, including flood and wet seasons (Hung et al., 2005) so ammonium contribution is currently not considered in this study. We 
conservatively assume the average upwelling area after a typhoon is approximately 20,000 $\mathrm{km}^{2}$. We do not have vertical transport velocity data of upwelling water after Typhoon Morakot. However, the upwelling velocity after Typhoon Morakot should be significantly higher than $5.4 \mathrm{~m} /$ day (Liu et al., 1992), because temperature and nitrate concentration in the surface water cannot change rapidly in just two days (water only moves about $11 \mathrm{~m}$ ) after the passage of Typhoon Morakot. We can use two approaches to estimate the nitrate transport in the SECS. First, we used temperature as a proxy to estimate upwelling speed. The temperature at $75 \mathrm{~m}$ in the study area during July $21-22$ ranged from 20.4 to $21.8^{\circ} \mathrm{C}$. The temperature at $70 \mathrm{~m}$ in the study area on Aug. 5 was about $20 \sim 21^{\circ} \mathrm{C}$.

As previously mentioned, the first cooling event in the study area was mainly caused by the cold upwelled water. We assume that the center of upwelling water did not mix with surrounding water while it first came out from the Kuroshio subsurface water. Based on the temperature data, the water sources should then be from about $60 \mathrm{~m}$. Second, the surface nitrate concentrations in the center of upwelling water two days after Typhoon Morakot was $5.1 \mu \mathrm{M}$. The nitrate concentrations at $50 \mathrm{~m}$ and $70 \mathrm{~m}$ in the center of upwelling water on July 22 were 3.3 and $7.1 \mu \mathrm{M}$, respectively. Remarkably, the source of nitrate should be from water deeper than $50 \mathrm{~m}$ and $60 \mathrm{~m}$ should be a reasonable depth. The estimated upwelling velocity would then be $24 \mathrm{~m} /$ day ( $=60 \mathrm{~m} / 2.5$ days), if a time period of 2.5 days (Aug. 9-11) was considered. In fact, the upwelling velocity at the center of upwelling should be the maximum, if the upwelling velocity decreases along the center to the edge of the upwelling area. The average upwelling velocity in the whole cold water patch would then be $12 \mathrm{~m} /$ day. The upwelling velocity yielded a total volume transport of $0.6 \times 10^{11} \mathrm{~m}^{3} /$ day to the top $75 \mathrm{~m}$ in the upwelling area of $10,000 \mathrm{~km}^{2}$. The nitrate transport would then be $0.52 \times 10^{12} \mathrm{~g}-\mathrm{N} /$ day to the top from $75 \mathrm{~m}$ in the averaged upwelling area of $10,000 \mathrm{~km}^{2}$ if an average nitrate concentration of $7.5 \mu \mathrm{M}$ was used. The net nitrate transport from the oceanic source after Typhoon Morakot would then be $0.52 \times 10^{12} \mathrm{~g}-\mathrm{N} /$ day to the water column $(0-75 \mathrm{~m})$ if a time period of 0.5 day was adopted.

Alternatively, as observed in Figure 3, the water masses around the cold dome region are not a simple one-dimensional mixing process. Tsai et al. (2013) used a modified numerical ocean model to simulate the cold dome (i.e. upwelling) region in the SECS affected by Typhoon Morakot. Tsai et al. (2013) reported that a large upwelling zone was converging at depth and diverging at the surface, and lasted for approximately two days. The detailed description of such an upwelling mechanism can be found in Tsai et al. (2013). The vertical upwelling speeds in the water column $(0 \sim 140 \mathrm{~m})$ were approximately 0.00 to $0.06 \mathrm{~cm} / \mathrm{s}$ at $25.45^{\circ} \mathrm{N}, \sim 122^{\circ} \mathrm{E}$, and 0.01 to $0.08 \mathrm{~cm} / \mathrm{s}$ at $24.9^{\circ} \mathrm{N}, \sim 122^{\circ} \mathrm{E}$ from Aug. $7-8$ within 36 hours, respectively (Tsai et al., 2013). Tsai et al. (2013) also reported that the vertical downwelling speeds in the water column were approximately -0.02 to 0 (on average -0.01 $\mathrm{cm} / \mathrm{s})$ at $24.9^{\circ} \mathrm{N}, \sim 122^{\circ} \mathrm{E}$ from Aug. $8-9$ within 24 hours. If we use the averaged upwelling speed $(0.03 \mathrm{~cm} / \mathrm{s})$ and $(0.045 \mathrm{~cm} / \mathrm{s})$, the vertical upwelling speed would be approximately $26 \mathrm{~m} /$ day and $39 \mathrm{~m} /$ day, respectively. In other words, the net mean vertical upwelling speed is $23.8 \mathrm{~m} /$ day, if the average downwelling speed $(-0.01 \mathrm{~cm} / \mathrm{s})$ is subtracted. The nitrate 


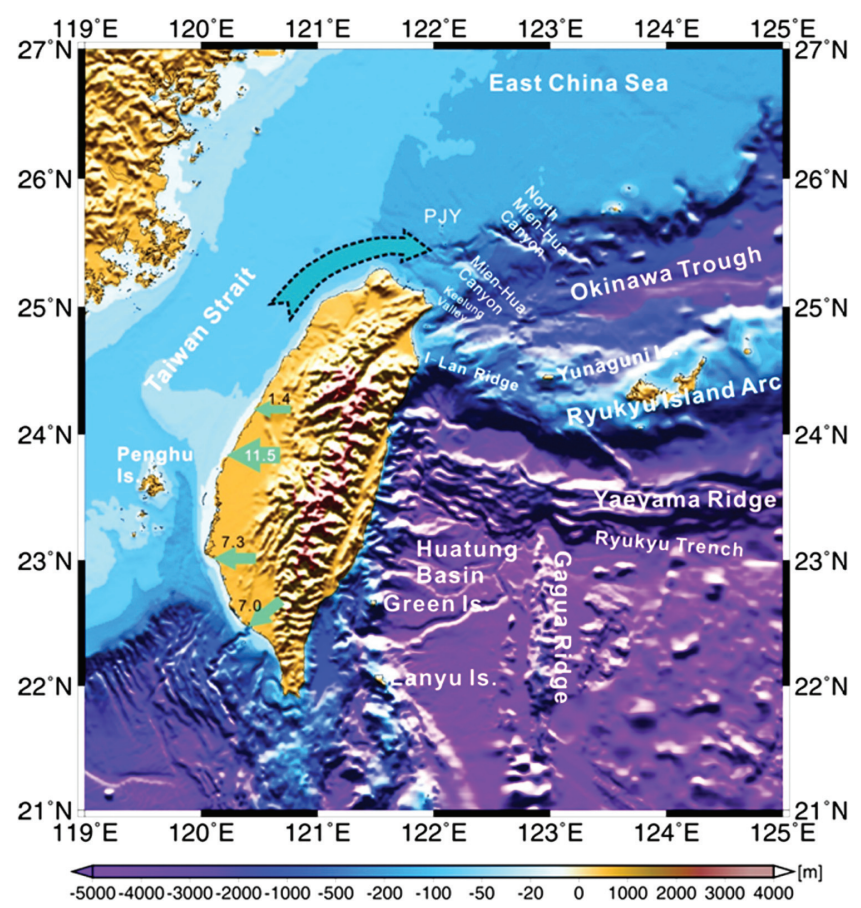

Figure 5. Schematic diagram showing the possible fresh water transport $\left(\mathrm{in} \mathrm{km}^{3}\right)$ from southern rivers after Typhoon Morakot. The river runoff of each river was integrated from Aug. 6-10.

transport would be $1.05 \times 10^{12} \mathrm{gN} /$ day to the top from $75 \mathrm{~m}$ in the average upwelling area of $10,000 \mathrm{~km}^{2}$ if an average nitrate concentration of $7.5 \mu \mathrm{M}$ was used. The nitrate transport from the oceanic source after Typhoon Morakot would then be $5.6 \times 10^{11} \mathrm{~g}-\mathrm{N} /$ day to the top of water column if a time period of 0.5 day $(=1.5-1.0$, considering the time difference of upwelling and downwelling) and the same volume water mass is adopted. The estimated net nitrate transport to the top $75 \mathrm{~m}$ will then be $0.56 \times 10^{12} \mathrm{~g}-\mathrm{N}$ after Typhoon Morakot if removal of sinking nitrogen flux $(0.1 \mu \mathrm{M}-\mathrm{N}$, Hung et al., unpublished data) and DON $(\sim 15 \%$ of nitrate $=0.43 \mu \mathrm{M}-\mathrm{N})$ are considered. Using the same computation as above, the net phosphate transport after Typhoon Morakot would be $7.8 \times 10^{10} \mathrm{~g}-\mathrm{P} / \mathrm{day}$, if we use the average ratio (11.4) of DIN/P after Typhoon Morakot during the period of Aug. 11, 14 and 18.

As mentioned previously, the nutrient supply in the SECS after Typhoon Morakot came primarily from oceanic (e.g. the Kuroshio subsurface water) and terrestrial (river runoff) sources. An easy way to estimate total nitrogen transport is to estimate the total volume of fresh water and the average concentration of nitrogen in the river water. While the total volume of fresh water dumped to southern Taiwan was about $3.2 \times 10^{10} \mathrm{~m}^{3}$ (Jan et al., 2013), the net transport volume of fresh water to the Taiwan Strait was approximately $2.8 \times 10^{10} \mathrm{~m}^{3}$ because the river discharge from the Gaoping River (Fig. 5) may have partly 


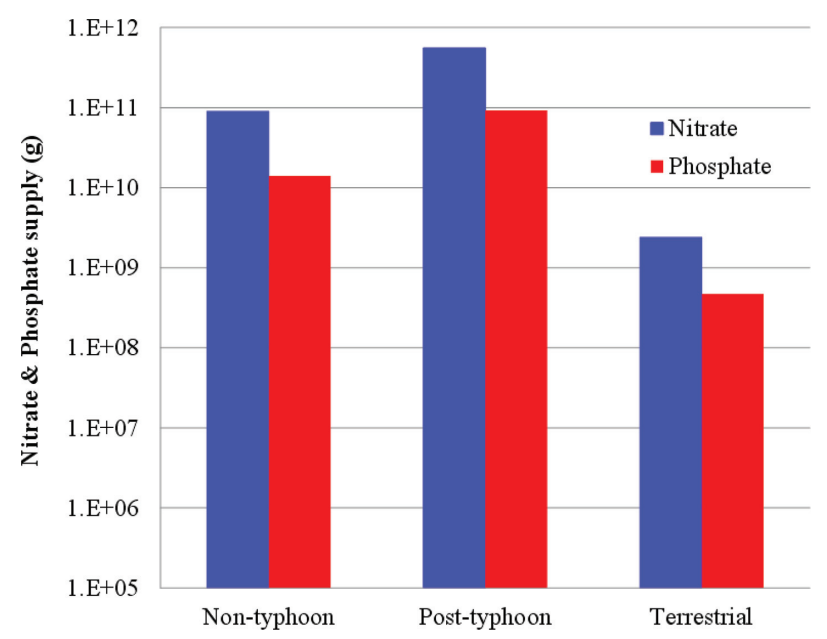

Figure 6. Estimated nitrate and phosphate transport via different sources (e.g. non-typhoon (a period of 90 days), post-typhoon and terrestrial input) to the southern East China Sea in summer.

gone southeastward (Jan et al., 2013). The total nitrate transport to the Taiwan Strait would be $2.4 \times 10^{10} \mathrm{gN}$ if the average nitrate concentration of $60 \mu \mathrm{M}$ (covering dry, flood and wet seasons) from Tsengwen River in southwestern Taiwan was adopted (Hung et al., 2005). As reported by Jan et al. (2013), a part of terrestrial fresh water would be transported to the East China Sea directly through the Taiwan Warm Current and nutrients would have been diluted by ambient seawater and consumed by phytoplankton. As a result, the maximum nitrate transport to the northern East China Sea off northern Taiwan should be approximately $2.4 \times 10^{9} \mathrm{~g}-\mathrm{N}$, if a rough dilution ratio (10:1) would be considered, considerably less than nitrate from upwelling. Using the same computation as above, the maximum phosphate transport to the northern ECS off northern Taiwan should be about $4.7 \times 10^{8} \mathrm{~g}-\mathrm{P}$, if we use the average ratio (11.4) of DIN/P after typhoon Morakot during the period of Aug. 11, 14 and 18 .

\section{c. Implications of nutrient supply in the ECS after Typhoon Morakot}

The estimated nitrogen transport to the SECS from oceanic and terrestrial sources after a typhoon thus is $5.6 \times 10^{11} \mathrm{~g}-\mathrm{N}$ and $2.4 \times 10^{9} \mathrm{~g}-\mathrm{N}$, respectively, suggesting that the oceanic source is the main source of nutrients (Fig. 6). The total nitrate supply in summer (including non-typhoon $\left(1.0 \times 10^{9} \mathrm{~g}-\mathrm{N} / \mathrm{d}\right)$ and after typhoon conditions $)$ in 2009 would be $6.5 \times 10^{11} \mathrm{gN}$, including $0.9 \times 10^{11}$ gN-nitrate supply from non-typhoon conditions ( $\sim 90$ days) (Fig. 6). Using similar computation of nitrate supply on phosphate, the total phosphate supply in summer (including non-typhoon $\left(1.6 \times 10^{8} \mathrm{~g}-\mathrm{P} / \mathrm{d}\right)$ and after typhoon conditions) in 2009 would be $9.2 \times 10^{10} \mathrm{~g}-\mathrm{P}$, including $1.4 \times 10^{10} \mathrm{~g}-\mathrm{P}$ supply from non-typhoon conditions ( $\sim 90$ days). The estimated nitrate and phosphate transport by oceanic and terrestrial sources 
is thus a significant improvement over previous estimates because sea-going observations after extreme atmospheric events (such as Asian dust storms or typhoons) are very limited and often ignored. Most importantly, the contribution of nitrogen and phosphate supply from oceanic sources in the SECS after Typhoon Morakot can account for about $86 \%$ of the nitrate supply and $87 \%$ of phosphate supply in the whole summer, respectively. If the results are close to the real oceanic conditions, the contribution of nitrate and phosphate supplies from oceanic sources after typhoons is major, and needs more attention.

An important question is, if the nitrate supply from upwelling after the typhoon is so high, why did we not see a phytoplankton bloom immediately (two-three days) after the typhoon passed? Nitrate concentrations were possible not rapidly consumed by phytoplankton because of several factors, water converging and diverging, hurricane wakes, phytoplankton intensive mixed from surface waters to greater depth. Shortly after the typhoon, phytoplankton biomass is expected to increase in response to higher nutrient concentrations and increasing water stability. After some more time the $\mathrm{Chl} a$ concentration (i.e. phytoplankton biomass) is likely to decrease again when nutrients are used up and their concentrations are decreasing. Additionally, light limitation and intense grazing pressure by copepods are possible reasons to constrain phytoplankton blooms (Hung et al., 2010; Chung et al., 2012). Moreover, the upwelled nitrate will be diluted and transported from the southern ECS to the northern ECS or the adjacent regions along the Kuroshio supporting phytoplankton bioactivity and associated fishery activity (Lin et al., 2013). The cold water patches are difficult to track and surface cooling may have quickly disappeared because waters are easily mixed with ambient warm water in the summer (e.g. SST images showed in Fig. 2). Furthermore, our estimated nutrient supply was integrated over $75 \mathrm{~m}$ where phytoplankton growth may be strongly limited by light. However, we did see a phytoplankton bloom tied to fresh water input and thus supported by the terrestrial nutrient sources occurring in the SECS about eight to 10 days after the passage of Morakot because the high nutrient terrestrial water that was mixing with surrounding water was getting more stable while they it was transported to the SECS off northern Taiwan from the southern Taiwan estuaries.

\section{Conclusion}

It is unquestionable that nutrient supply through episodic typhoon events in the SECS provides an important contribution for phytoplankton growth, and thus also for the production of zooplankton and larval fish. We estimated that the contribution of nitrogen and phosphate supplies from oceanic sources in the SECS after Typhoon Morakot can account for about $86 \%$ of the nitrate supply in the summer. These results suggest that abundant nutrients (accounting for $86 \%$ of nitrate and $87 \%$ of phosphate) induced by typhoons in the SECS in summer are indeed much larger than previously thought. It is necessary to conduct successive field observations to understand if the upwelled nutrient-rich water can be efficiently utilized in more remote areas away from the source water. 
Acknowledgments. We appreciate the assistance of the crew of the R/V Ocean Research II: G.-S. Hsieh, J.-M. Wu and C.W. Tseng. We also thank Dr. Peter Santschi for his comments. This research was supported by the Top University Program and the National Science Council (NSC101-2116M-110001, NSC101-2611-M-110-015-MY3, NSC100-2119-M-110-003, NSC98-2611-M-019-014-MY3, NSC NSC98-2611-M-002-019-MY3) of Taiwan to C.-C. Hung, G.-C.Gong and S. Jan.

\section{REFERENCES}

Alvarez-Salgado, X.A.; M.D. Doval and F.F. Prez. 1999. Dissolved organic matter in shelf waters off the Ra de Vigo (NW Iberian upwelling system). Journal of Marine Systems, 18, 383-394.

Babin, S.M.; J. A. Carton; T. D. Dickey and J.D. Wiggert. 2004. Satellite evidence of hurricaneinduced phytoplankton blooms in an oceanic desert. Journal of Geophysical Research, 109, C03043, doi:10.1029/2003JC001938.

Chang, Y.; H.-T. Liao; M.-A. Lee; J.-W. Chan; W.-J. Shieh; K.-T. Lee; G.-H. Wang and Y.-C. Lan. 2008. Multisatellite observation on upwelling after the passage of Typhoon Hai-Tang in the southern East China Sea. Geophysical Research Letters, 35, L03612, doi:10.1029/2007GL032858.

Chen, C.T.A.; C.T. Liu; W.S. Chuang; Y.J. Yang; F.K. Shiah; T.Y. Tang and S.W. Chung. 2003. Enhanced buoyancy and hence upwelling of subsurface Kuroshio waters after a typhoon in the southern East China Sea. Journal of Marine System, 42, 65-79.

Chen, Y.-L.L. 2000. Comparisons of primary productivity and phytoplankton size structure in the marginal regions of southern East China Sea. Continental Shelf Research, 20, 437-458.

Chen, Y. -L.L. and H.Y. Chen. 2003. Nitrate-based new production and its relationship to primary production and chemical hydrography in spring and fall in the East China Sea. Deep-Sea Research II, 50, 1249-1264.

Chen, Y.-L.L.; H.-Y. Chen; W.H. Lee; C.C. Hung; G.T.F. Wong and J. Kanda. 2001. New production in the East China Sea, comparison between well-mixed winter and stratified summer conditions. Continental Shelf Research, 21, 751-764.

Chen, Y.-L.L.; H.-Y. Chen; S. Jan and S.-H. Tuo. 2009. Phytoplankton productivity enhancement and assemblage change in the upstream Kuroshio after typhoons. Marine Ecology Progress Series, 385, 111-126.

Chern, C.S.; J. Wang and D.P. Wang. 1990. The exchange of Kuroshio and East China Sea shelf water. Journal of Geophysical Research, 95, 16017-16023.

Chou, W.-C.; G.-C. Gong; W.-J. Cai; D.-D. Sheu; C.-C. Hung; H.-Y. Chen and C.-C. Chung. 2011. $\mathrm{CO}_{2}$ system in the oligotrophic northwest Pacific Ocean during the Asian dust storm season. Marine Chemistry, 127, 210-222.

Chung, C.-C.; G.-C. Gong and C.-C. Hung. 2012. Effect of the tropical cyclone Morakot on microphytoplankton population dynamics in the subtropical Northwest Pacific. Marine Ecology Progress Series, 448, 39-49.

Chung, C-C.; J. Chang; G.-C.Gong; S.-C. Hsu; K.-P. Chiang and C.-W. Liao. 2011. Effects of Asian dust storms on Synechococcus populations in the subtropical Kuroshio Current. Marine Biotechnology, 13, 751-763.

Gong, G.C.; K.K. Liu; C.T. Liu and S.C. Pai. 1992. The Chemical Hydrography of the South China Sea west of Luzon and a comparison with the west Philippine Sea. Terrestrial Atmospheric and Oceanic Sciences, 3, 587-602.

Gong, G.-C.; K.-K. Liu and S.-C. Pai. 1995. Prediction of nitrate concentration from two end member mixing in the southern East China Sea. Continental Shelf Research, 15, 827-842.

Gong, G.-C.; F.-K. Shiah; K.-K. Liu; Y.-H.Wen and M.-H. Liang. 2000. Spatial and temporal variation of chlorophyll $a$, primary productivity and chemical hydrography in the southern East China Sea. Continental Shelf Research 20, 411-436. 
Gong, G.-C.; Y.H. Wen; B.W. Wang and G.J. Liu. 2003. Seasonal variation of chlorophyll a concentration, primary production and environmental conditions in the subtropical East China Sea. Deep-Sea Research II, 50, 1219-1236.

Huang, C.-Y.; C.-S. Wong and T.-C. Yeh. 2011. Extreme rainfall mechanisms exhibited by Typhoon Morakot (2009), Terrestrial, Atmospheric and Oceanic Sciences, 22, 6, doi: 10.3319/TAO.2011.07.01.01(TM)

Hung, C.-C.; G. T. F. Wong; K.-K. Liu; F.-K. Shiah and G.-C. Gong. 2000. The effects of environmental conditions on the relationship between nitrate reductase activity and ${ }^{15} \mathrm{NO}_{3}^{-}$uptake: field observations in the East China Sea. Limnology and Oceanography, 45: 836-848.

Hung, C.-C.; K.W. Warnken and P.H. Santschi. 2005. A seasonal survey of carbohydrates and uronic acids in the Trinity River, Texas. Organic Geochemistry, 36, 463-474.

Hung, C.-C.; G.C. Gong and H.Y. Chen. 2007. Relationships between pesticides and organic carbon fractions in sediments of the Danshui River estuary and adjacent coastal areas of Taiwan. Environmental Pollution. 148, 546-554.

Hung, C.-C.; G.-C. Gong; W.-C. Chung; W.-T. Kuo and F.-C. Lin. 2009. Enhancement of particulate organic carbon export flux induced by atmospheric forcing in the subtropical oligotrophic northwest Pacific Ocean. Marine Chemistry, doi:10.1016/j.marchem.2008.11.004.

Hung, C.-C. and G.-C. Gong. 2011. Biogeochemical responses in the southern East China Sea after typhoons. Oceanography, 24, 4, 42-51.

Hung, C.-C.; G.-C. Gong; W.-C. Chou; C.-C. Chung; M.-A. Lee; Y. Chang; H.-Y. Chen; S.-J. Huang; Y. Yang; W.-R. Yang; W.-C. Chung; S.-L. Li and E. Laws. 2010. The effect of typhoon on particulate organic carbon flux in the southern East China Sea, Biogeosciences, 7, 3521-3550, doi:10.5194/bg7-3007-2010.

Hung, C. -C.; G. C. Gong and P.H. Santschi, 2012. 234Th in different size classes of sediment trap collected particles from the Northwestern Pacific Ocean. Geochimica et Cosmochimica Acta, 91, 60-74, doi: 10.1016/j.gca.2012.05.017.

Hung, J.J. and M.-H. Huang. 2005. Seasonal variations of organic-carbon and nutrient transport through a tropical estuary (Tsengwen) in southwestern Taiwan. Environmental Geochemistry and Health, 27, 75-95.

Jan, S.; C.C. Chen; Y.L. Tsai; Y.J. Yang; J. Wang; C.S. Chern; G. Gawarkiewicz; R.C. Lien; L. Centruioni and J.Y. Kuo. 2011. Energetic variability of cold dome northeast of Taiwan. Oceanography, 24, 4, 100-109.

Jan, S.; J. Wang; Y.J. Yang; C.C. Hung; C.-S. Chern; G. Gawarkiewicz; R-C. Lien; L. Centurioni; J-Y. Kuo and B. Wang. 2013. Observation of a freshwater pulse induced by Typhoon Morakot off northern coast of Taiwan in August 2009. J. Mar. Res. 71(1-2), 19-46.

Li, C.; E. Weeks and B. W. Blanchard. 2010. Storm surge induced flux through multiple tidal passes of Lake Pontchartrain estuary during Hurricanes Gustav and Ike. Estuarine, Coastal and Shelf Science, 87, 517-525.

Li, J.; P.M. Glibert; M. Zhou; S. Lu and D. Lu. (2009) Relationships between nitrogen and phosphorus forms and ratios and the development of dinoflagellate blooms in the East China Sea. Marine Ecology Progress Series, 383, 11-26.

Liu, J.T.; S.-J. Kao; C.-A. Huh and C.-C. Hung, (2013) Gravity flows associated with flood events and carbon burial: Taiwan as instructional source area. Annual Reviews of Marine Sciences. 5, 47-68.

Liu, K.K.; G.-C. Gong; S. Lin; C.Y. Wang; C.L. Wei and S.Y. Chao. 1992. The year-round upwelling at the shelf break near the northern tip of Taiwan as evidenced by chemical hydrography. Terrestrial Atmospheric and Oceanic Sciences, 3, 243-275.

Liu, K.K.; Z.L. Lai; G.C. Gong and F.K. Shiah 1995. Distribution of particulate organic matter in the Southern East China Sea: implications in production and transport. Terrestrial Atmospheric and Oceanic Sciences, 6, 27-45. 
Liu, K.K.; L. Atkinson; R. Quiñones and L. Talaue-McManus. 2010. Carbon and Nutrient Fluxes in Continental Margins: A Global Synthesis. IGBP Book Series, Springer, Heidelberg, Germany. $744 \mathrm{pp}$.

Morimoto, A.; S. Kojima; S. Jan and D. Takahashi. 2009. Movement of the Kuroshio axis to the northeast shelf of Taiwan during typhoon events. Estuarine, Coastal and Shelf Science, 82, 547552, doi: 10.1016/j.ecss.2009.02.022.

Redfield, A.C.; B.H. Ketchum and F.A. Richard. 1963. In The Sea (ed. Hill, M. N., Interscience Press, New York, 26-77.

Sassa, C.; Y. Tsukamoto; K. Nishiuchi and Y. Konishi. 2008. Spawning ground and larval transport processes of jack mackerel Trachurus japonicas in the shelf-break region of the southern East China Sea. Continental Shelf Research, 28, 2574-2583.

Siswanto, E.; J. Ishizaka; K. Yokouchi; K. Tanaka and C.K. Tan. 2007. Estimation of interannual and interdecadal variations of typhoon-induced primary production: a cases study for the outer shelf of the East China Sea. Geophysical Research Letters, 34, L03604, doi:10.1029/2006GL028368.

Siswanto, E.; J. Ishizaka; A. Morimoto; K. Tanaka; K. Okamura; A. Kristijono and T. Saino. 2008. Ocean physical and biogeochemical responses to the passage of Typhoon Meari in the East China Sea observed from Argo float and multiplatform satellites. Geophysical Research Letters, 35, L15604, doi:10.1029/2008GL035040.

Siswanto, E.; A. Morimoto and S. Kojima. 2009. Enhancement of phytoplankton primary productivity in the southern East China Sea following episodic typhoon passage. Geophysical Research Letters, 36, L11603, doi:10.1029/2009GL037883.

Tsai, Y.; C.-S. Chern and J. Wong. 2008. Typhoon induced upper ocean cooling off northeastern Taiwan. Geophysical Research Letters, 35, L14605, doi:10.1029/2008GL034368.

Tsai, Y.; C.-S. Chern; S. Jan and J. Wang. 2013. Numerical study of cold dome variability induced by Typhoon Morakot (2009) off northeastern Taiwan. J. Mar. Res. 71(1-2), 109-132.

Walker, N.D.; A. Haag; S. Balasubramanian; R. Leben; I.V. Heerden; P. Kemp and H. Mashriqui. 2006. Hurricane prediction: a century of Advances. Oceanography. 19, 24-36.

Walker, N. D.; R. R. Leben and S. Balasubramanian. 2005. Hurricane-forced upwelling and chlorophyll $a$ enhancement within cold-core cyclones in the Gulf of Mexico, Geophysical Research Letters. 32, L18610, doi:10.1029/2005GL023716.

Wang, K.-Y.; C.-H. Liao and K.-T. Lee. 2008. Population and maturation dynamics of the swordtip squid (Photololigo edulis) in the southern East China Sea. Fisheries Research 90, 178-186.

Yen, T.-H.; C.-C. Wu and G.-Y. Lien. 2011. Rainfall simulation of Typhoon Morakot with controlled translation speed based on EnKF data assimilation, Terrestrial, Atmospheric and Oceanic Sciences, 22, 6, doi: 10.3319/TAO.2011.07.05.01(TM)

Zhao, H.; D. Tang and Y. Wang. 2008. Comparison of phytoplankton blooms triggered by two typhoons with different intensities and translation speeds in the South China Sea. Marine Ecology Progress Series, 365, 57-65.

Zheng, G.M. and D.L. Tang. 2007. Offshore and nearshore chlorophyll increases induced by typhoon winds and subsequent terrestrial rainwater runoff. Marine Ecology Progress Series, 333, 61-74.

Received: June 27, 2012; Revised: Feb. 4, 2013. 